Faba, Phaseolus, Dicentra, and the vine, and some interesting remarks on methods, \&c., were made in the discussion which followed.

On the Coloration of the Anterior Segments of the Maldanide, by Allen Harker, F.L.S., Professor of Natural History, Royal Agricultural College, Cirencester.--The author, while studying the circulation and respiration of annelids at the zoological station at Naples, had been specially interested in the Maldanidæ, from their partially tubiculous habit and the brilliant coloration of their anterior segments. The bands of colour usually ornament the anterior segments, beginning with the second or third, and continuing to the ninth; but the distribution of the coloured hands differs widely in the different species. The colour in living or freshly-killed specimens is of a rich rose madder colour, shading off in each segment to a brighter rose-pink hue. Quatrefages attributed a physiological value to these coloured bands, describing them as being connected with the respiratory function. In connection with the whole subject of cutaneous respiration in annelids, it appeared important to settle this question, and the author made sections of the anterior segments in the Maldanidæ, and finds the colour to be due to a special pigment, whose behaviour under various reagents he described. On the other hand the author has studied the blood-vessels and their distribution in the living chætopod, and is satisfied that it extends equally in those portions of the cuticle which are uncoloured as in those which are. The coloured bands do not appear, therefore, to be in any way connected with the function of respiration.

\section{SECTION E-GEOGRAPHY}

The Indian Forest School, by Major F. Bailey, F.R.G.S., Royal Engineers, Director of the School.-It is only within the last twenty-five years that a special State department has administered the Indian forests. The staff was at first composed of men who had received no professional education, but they were able to do all that was then needed, and they accomplished work of great value. But as a result of their work the State became possessed of large forest areas, from which a permanent supply of produce had to be sectred, and which had therefore to be managed systematically. At this time nothing was known of systematic forestry in England or in India, and an arrangement was made in 1866 under which candidates for the Indian Forest Service were trained on the Continent. The arrangement with the French Government is still in force, but it has now been decided to undertake the instruction in England. Great progress has been made in Indian forestry, which is mainly due to the professionally-trained men with whom the Forest Department has been recruited, but up to 1869 nothing bad been done towards the education of the subordinate ranks. As work requiring professional skill became necessary over large areas, it was found that the "divisions" must be broken up into a number of smaller executive charges under natives of the country, and that they must receive a professional education. In $1869 \mathrm{Mr}$. Brandis made proposals to organise the subordinate grades and to train men at the Civil Engineering Colleges, and several other attempts were made in the same direction, but without marked success. In $1878 \mathrm{Mr}$. Brandis proposed to establish a Central Forest School, and his proposals were accepted by Government. The chief object of the School was then to prepare natives of India for the executive charge of forest ranges, and to qualify them for promotion to the superior staff, but it was hoped that the school might ultimately be used to train candidates for the controlling branch. The chief forest officers of provinces were to select candidates and send them to be trained at the School. None but natives of India were to be admitted. A number of forests near Dehre Dun were grouped together as a training ground and placed under a separate conservator, who was also appointed director of the school. A board of inspection was appointed. The first theoretical course was held in 1881, and they have been held every year since then. The present system is that the candidates, who must be in robust health, are selected by conservators of the forest or by the director of the school. They must serve in the forests for at least twelve months before entering the School. Candidates for the ranger's certificate must have passed the entrance examination of an Indian University on the English side ; candidates for the forester's certificate pass a lower examination. The course of training for these two classes extends over eighteen and twelve months respectively. Men who gain the certificates return to their provinces, and are employed there. The course of instruction for the ranger's class embraces vegetable physiology, the elements of physics and chemistry, mathematics, road making and building, surveying, sylviculture, working plans, forest utilisation, forest botany, the elements of mineralogy and geology, forest law, and the elements of forest etiology. The course for foresters is much more simple. The preparation of manuals is in progress, and a library, museum, chemical laboratory, observatory, and forest garden have been established. The period of probation in the forest before entry into the School has a twofold object : firstly, to enable the theoretical course to be understood; secondly, to eliminate men who are unsuited to a forest life before time and money have been spent on their training. As a rule, the students are employés of the Forest Department, and they draw their salaries and maintain themselves while at the School. No instruction fees are charged. It would not at present be possible to get condidates whose maintenance and education are entirely paid for by their friends. Nine men who have left the School have appointments of from 125l. to $200 l$ a year, and this ought to draw eligible candidates. Conservators of forests say that the men trained at the School are markedly superior to their untrained comrades. The area of reserved forests has largely increased of late, and the prospects of the students are very good. During the session of 1884 there were forty-six students of all classes at the School, of whom eight were from Madras, and seven from native States, the chiefs of which have been induced by the establishment of the school to take measures for the protection of their forests. The School has now been made an imperial institution, and this is a great advantage in every way. The expenses of the School in 1884 are said to have been IgIIl.

On Fourneyings in South-Western China, by A. Hosie.-In the autumn of I881 Mr. Hosie was appointed Her Majesty's Agent in Western China, and reached Ch'ung-ch'ing, in the province of Ssur-ch'uan, in January, I882. From this point he made three journeys in South-Western China. In the spring of I 882 he proceeded through Southern Ssŭ-ch 'uan and Northern Kuei-chou, the Chinese "Switzerland," to Kuei-yang Fu, the capital of the latter province, whence he journeyed westward in the footsteps of Margary to the capital of Yuinnan. From Yünnan $F u$ he struck north-east through Northern Yünnan, following for days here and there the routes of Garnier and the Grosvenor Mission. At last he descended the Nan-kuang River and reached the right bank of the Great River, the local name of the Upper Zangtsze, at a point below Hsii-chou Fu, an important city at the junction of the Min River and the Chin-sha Chiang, or River of Golden Sand. Here he took boat and descended the Great River to $\mathrm{Ch}^{\text {' } u n g-c h}$ 'ing, his starting-point. In February, I883, Mr. Hosie again left $\mathrm{Ch}^{\text {' }} \mathrm{ung}$-ch'ing, and proceeded north-west to $\mathrm{Ch}$ 'êng-tu, the capital of the province of Ssur-ch'uan, by way of the brine and petroleum wells of Tzŭ-liu-ching. From Ch 'êng-tu he journeyed west and southwest through the country of the Lolos, skirting the western boundary of Independent Lolodom. From Ning-yiian, locally called Chien-ch'ang, and lying in a valley famous, among other things, as the habitat of the white-wax insect, he passed southwest through the mountainous Cain-du of Marco Polo, inhabited in great part by Mantzŭ tribes, and struck the left bank

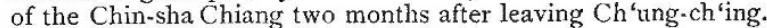
From this point Ta-li $\mathrm{Fu}$, in Western Yünnan, was easily reached. From Ta-li $\mathrm{F}_{\mathrm{u}} \mathrm{Mr}$. Hosie jurneyed eastward to $\mathrm{Y}$ ünnan $\mathrm{Fu}$, which he had visited the year before, and then struck north-east through Western Kuei-chou to the Yung-ning River, which he descended to the Great River. Lu Chou, an important city at the junction of this river with the $\mathrm{T}^{\circ} \mathrm{O}$ River, was soon reached, and the Great River was again descended to Ch'ung-ch'ing. This journey occupied four months. In June, 1884, Mr. Hosie again left Ch'ung-ch'ing, and from Ho Chou, a three days' journey to the north of that city, he struck westward through a beautifully cultivated and fertile country to Chiating $\mathrm{Fu}$, on the right bank of the Min at its junction with the $T^{\prime}$ ung River. Chia-ting is famous as the great centre of sericulture in Ssŭ-ch'uan, and as the chief insect wax-producing country in the Empire. A day's journey west of Chia-ting is the famous Mount O-mei, rising I I, 100 feet above the level of the sea. This mountain, which is sacred to the worship of Buddha, Mr. Hosie ascended in company with crowds of pilgrims. He then proceeded south, skirting the eastern boundary of Independent Lolodom, to the River of Golden Sand, the left bank of which was struck at the town of Man-i-ssŭ, between 
forty and fifty miles above $\mathrm{P}$ 'ing-shan Hsien-the highest point reached by the Upper Yangtsze Expedition in 1861 . From Man-i-ssu Mr. Hosie descended the Chin-sha Chiang and the

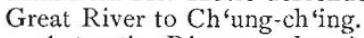

An'arctic Discovery, by Admiral Sir Erasmus Ommanney, C.B., F.R.S. - The object of this paper is to draw attention to the neglect of the Antarctic region as a field for exploration. The author gives a summary of the work which has already been done by Cork, Bellingshausen, Weddell, Biscoe, Balleny, Wilkes, Dumont d'Urville, James Ross, and Nares (in the Challenger). The author refers to a paper by Dr. Neumayer on the subject, the substance of which was reproduced in NATURE (vol. vii. p. 2I). The author concludes as follows:I have thus laid before you but a very imperfect description of these voyages; to give the details of the scientific results would occupy a separate paper. But I have endeavoured to demonstrate how large a field remains open for discovery. I think, from all we now know, we may infer that the South Pole is capped by an eternal glacier; and, from the nature of the soundings obtained by koss, it would appear that the great icewall along which the ships navigated was the termination of the glacier-the source from which the inexhaustible supply of icebergs and ice-islands are launched into the Southern Ocean, many of which drift to the low latitude of $42^{\circ}$. The fact of finding the volcanoes of equal proportions to Etna or Mont Blanc creates a zest for further research regarding that awful region on which neither man nor quadruped ever existed. No man has ever wintered in the Antarctic zone. The great desideratum now before us requires that an expedition should pass a winter there, in order to compare the conditions and phenomena with our Arctic knowledge. The observations and data to be collected there throughout one year could not fail to produce matter of the deepest importance to all branches of science. I believe that such an achievement can be accomplished in these days with ships properly designed and fitted with the means of steam propulsion; nor is it chimerical to conceive a sledge party travelling over the glacier of Victoria Land towards the South Pole, after the example of Nordenskjöld in Greenland. Another interesting matter requires investigation, from the fact that all the thermometers supplied for deep-sea temperatures to Ross were faulty in construction, as they were then not adapted to register accurately beneath the weighty oceanic pressure. Moreover, another magnetic survey is most desirable in order to determine what secular change has been made in the elements of terrestrial magnetism after an interval of forty years and more, when taken by Ross. In fact, there exists a wide field open for investigation in the unknown South Polar Sea. This paper will, I trust, be the prelude for others to follow in arousing geographers and this powerful Association in promoting further research by despatching another South Polar expedition, having for its object to secure a wintering station. No other nation is so capable of providing and carrying it out. Even in the Australian colonies there exists the spirit and the means for such a noble enterprise.

Projected Restoration of the Reian Moris, and the Province, Lake, and Canals ascribed to the Patriarch Foseph, by Cope Whitehouse, M.A., F.A.G.S.-The Berlin Geographical Society has published, in its Zeitschrift for May, I885 (No. II6), the latest map of Egypt, from the Fayoum to Behnesa, and from the Nile to the Little Oasis. The text by Dr. Ascherson gives credit for a considerable area to the topographical observations presented to this society at Montreal. So much of the Reian basin as lies between the Quasr Qerūn and the Quasr Reian has not been visited by any European except the author of this paper (1882, 1883). It is now an accepted fact that there is a depression south of the Fayoum, not less than 150 feet below the level of the Mediterranean, with a superficial area at the level of high Nile of several hundred square miles. It is irregular in shape, curving like a horn from a point near Behnesa to the ridge which separates it from the Fayoum. In the southern part are two, and perhaps three, patches of vegetation, wild palm-trees, and ruins of Roman and early Christian date. This part was visited by Belzoni, May 22, I819; Caillaud, November 24, 1819; Pacho and Müller, 1823-24; Sir G. Wilkinson, I825; Mason Bey, I870; and Ascherson, March 27, 1876. Dr. Ascherson determined by aneroid observations that his camp was 29 metres below the sea. Caillaud found ruins about $+38 \mathrm{~m}$., or about the level of high Nile in the valley on the same latitude. The aneroid, theodolite, and other observations of March 6 and April 4, 1882, and April, 1883, by the author of this paper, established a depth of -175 to -180 English feet. The greatest depth is probably under the western cliffs south of the Haram Medhūret el-Berl. No previous explorer had conceived it possible that this might have been a lake within historic times. The level of the ruins, as determined by Caillaud, shows that the ancient station of Ptolemais might have been, as represented in the text and maps of Claudius Ptolemy, on a horn-shaped lake about 35 miles long and 15 wide, with a maximum depth of 300 feet, fed by a canal, partly subterranean, from Behnesa, as well as by a branch of the present Bahr Jüsuf communicating with it through the Fayoum. 'T he lower plain of the Fayoum had been, at that time, fully redeemed, and the present Lake of the Horn reduced to such insignificant dimensions as to be unnoticed. The restoration of the Reian basin of Lake Mœris and the drainage by evaporation of the Birket elQuerūn would be a repetition in modern times of the best results reached in the Greco-Roman period, perhaps 3000 years after the first effort to utilise these two unique basins for storage and drainage.

On Batho-hypsographical Maps, with Special Reference to a Combination of the Ordnance and Admiralty Surveys, by E. G. Ravenstein. - The batho-hypsographical map, which exhibits the vertical configuration of the solid surface of the earth, above as well as below the ocean levels, is a product of modern times. It was Gerard Mercator who first inserted soundings upon a chart in 1585 , but nearly two centuries passed away before Cruquins, in 1728, introduced the fathom-lines with which we are all familiar. Buache, and after him Ducarla, first suggested the introduction of contours upon maps, and their idea was realised in I79I by Dupain-Triel on a map of France. The combination of these two descriptions of contoured maps we owe to modern German geographers, and more especially to Berghans, Von Sydow, and Ziegler. Cartographers, in effecting this combination, had hitherto quite lost sight of the fact that the heights on maps are referred to high or mean water, whilst the depths on charts represent soundings reduced to low water. This rough method gave satisfactory results when dealing with maps on a small scale, but a more rigid method would have to be applied when it was desired to combine accurate surveys like those made by the Ordnance and Admiralty Departments. The so-called mean level of the sea was not a suitable datum level, and it would be necessary to carry on tidal and other scientific observations on a far more comprehensive plan than had been done hitherto if a really satisfactory batho-hypsographical map of the British Islands were to become attainable. These various supplementary surveys, tidal observations, \&c., it was to be hoped, would expand into a comprehensive scientific survey of the British seas.

What has been done for the Geography of Scotiand, and what remains to be done, by $\mathrm{H}$. A. Webster. - After remarking on the unsatisfactory state of the Ordnance Maps, Mr. Webster said that in regard to the depth of our lakes and rivers-and the submerged portion of a valley is geographically as interesting as the sub-aèrial portion-absolutely no data are supplied by the Ordnance Survey. Nor, with a few individual exceptions, do they exist in an accurate and trustworthy form anywhere else. It was an open secret that, when this omission was pointed out to the Government by the Royal Societies of London and Edinburgh, the Lords of the Treasury refused, and aga in refused, to authorise a bathymetric lake and river survey being carried out, either by the officers of the Ordnance Survey or by those of the Hydrographic Department. Such a refusal could not be permanently accepted. It was to be hoped that when the Government was next urged to move in the matter they would be asked for more, and not for less. We requir d not only a hydrographic survey done once and for all (thorgh that was worth the doing); we required a systematic registration of hydrographic facts throughout the country, in order that the true regime both of lakes and rivers may be known in detail and with scientific precision. The ignorant niggardliness of the British Government was in striking contrast to the conduct of those of some foreign countries. In Switzerland, for instance, there was a regular system of inland hydrographic observations, by which the régime of all the principal rivers was annually recorded and rendered easily intelligible by a series of graphic bulletins. In regard to a Swiss river we could tell the volume at any period of the year at several important points, and could compare the facts of 1884 , for instance, with those of any year in the last two decades. Every one knew what a vast body of interesting data had for generations been accumulating about 
such rivers as the Po and the Rhone, and many had no doubt heard of the system of hydrographic stations recently established by the Italian Government in the basin of the Tiber. Why should we not endeavour to learn something definite and precise about the character of our own rivers? The investigation was only the natural complement, on the one hand, of the physical structure of the country, and, on the other hand, of its meteorology. Our Scottish Meteorological Society had now succeeded in establishing meteorological stations throughout the country; let hydrographic stations bear them company along our principal rivers. Rainfall and river discharge were mutually illustrative.

On Overland Expeditions to the Arctic Coast of America, by John Rae, M.D., F.R.S.-The following table shows the approximate amount of geographical work done by the expeditions under-

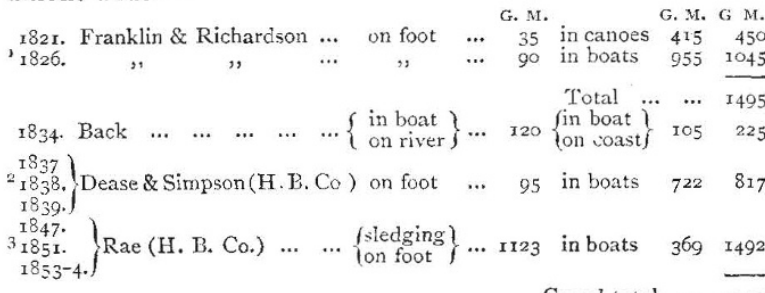

Grand total $\cdots \quad 4029$

A Word or Tivo on the Best and Safest Route by which to attain a High Norther'n Latitude, by John Rae, M.D., LL.D., F.R.S., F.R.G.S., \&c.-The plan proposed is that the route by the west shore of Spitzbergen should be taken by one, or perhaps two, steamers similar to the fine vessels used in sealing and whaling at the present time. That after forcing the ice "pack" at the north-west end of Spitzbergen, a north-east course towards Franz-Josef Land should be followed. That a depôt of coals should be placed at a convenient harbour in North Spitzbergen. Extracts are given from Parry's "Narrative," I827, pp. IOI and I48, showing how open and small the ice was in latitude $82^{\circ} 45^{\prime} \mathrm{N}$. The southern drift of the ice that so obstructed the advance of Parry's boats will be no great impediinent to a powerful steamer, whilst if she gets helplessly fixed in the pack she will drift homewards with it. No well-equipped and powerful steamer has tried this route.

\section{APANESE TA TTOOING}

[HE last number (Heft 32, May, 1885) of the Mittheilungen der deutschen Gesellschaft fiir Natur- und Völkerkunde Ostasiens is almost wholly occupied by a paper of a most exhaustive character by Dr. Baelz, a physician in the service of the Japanese Government, on the physical qualities of the Japanese. A previous paper by the same writer gave the results of his in ve:tigations into Japanese skeletons. For the purposes of the present paper he obtained numerous anthropometrical measurements-about 2500 -based on a scheme which included seventynine measurements in the case of each individual. It is noticeable that Broca confined himself to little more than a third of this number, Virchow's scheme contemplated thirteen, and at the most thirty-eight, Weissbach sixty-seven, and Quetelet, in his anthropometry, gives eighty-two measurements. The skeleton plan of the paper is as follows : $\mathrm{x}$. Skin and hair: the colour of the skin and its cause, artificial colouring, including tattooing, the characteristics and nature of the hair; 2 . The physique in general, including the carriage and gait of both sexes, weight, size, and growth ; 3. Measurements of the body and limbs. In the discussion of the results set forth in this section the author expresses the opinion, based on his own investigations, that in general the value of these anthropometrical measurements is much exaggerated by anthropologists and ethnographers.

The tattooing of the skin by Japanese, generally those of the lower classes, has attracted much observation from Europeans, due partly to the extraordinary elaboration and artistic skill displayed, partly to the fact that the occupations and customs of the class in which tattooing is most practised are such as to render it necessary frequently to wear none but the most

I Actually two expeditions-one east, the other west.

2 Dease and Simpson had to pass over about 500 miles of previously traced coast before getting to new ground, but Franklin and Richardson were on new ground at once on reaching the coast.

3 Of the coast, \&c., traced by Rae, 123 miles were done by sledging, believed to be the most laborious of Arctic work. indispensable garments. This subject has never, so far as we are aware, been examined with so much thoroughness and care as by Dr. Baelz. He says that among the various peoples which have, in the course of centuries, reached a high standard of culture the Japanese are probably the only race which have retained generally the practice of tattooing and have brought it to a state of highly artistic development. Up to a few years ago the practice was so widespread that in Tokio alone there are estimated to have been, possibly still are, 30,000 men who were tattooed. This decoration is not confined, as in Western countries, to a small part of the body, but it covers the whole back and a considerable part of the limbs. The head, neck, hands, and feet are never tattooed, a circumstance of importance in explaining the practice. It was confined to the lower classes; amongst the better classes it was considered unworthy to disfigure the body in this way. It was widely spread amongst the workmen in great towns and coolies, and even to-day it is exceptional to find an old man of either of these occupations who is not tattooed. The objects illustrated were various : amongst the most common were large dragons, lions, battle scenes, beautiful women, historical occurrences, flowers, \&c. Dr. Baelz states that he never saw obscene pictures tattooed. The colours employed are black, which appear blue, and various shades of red. The first is obtained from Indian ink, the usual Japanese writing material, the red from cinnabar. When a man wishes to undergo the process he looks out in a popular picture-book some illustration which takes his fancy, or he evolves something from his own imagination, and goes with it to the artist. The latter makes his arrangements, and sketches the picture on the skin. If he is skillful at his calling he sketches the merest outline, and straightway introduces all the details; but if he is not so confident in himself he first draws the whole picture on the skin. There is no special ceremony attending the work as in some of the South Sea Islands, nor is there any religious signification what ever in the process. The artist use; for the purpose exceedingly fine, sharp sewing needles, fixed firmiy, four, eight, twelve, twenty, or forty together, in a piece of wood. They are arranged in several rows; when there are forty they stand in fur rows of ten each. The points are quite even, except when it is desired to produce a light or dark shading, when the needles are arranged in corresponding lengths. This combination is said to be especially painful. The skin, at the place where the puncturing is going on, is stretched between the thumb and first finger of the operator, who holds between the third and fourth fingers of the same hand a writing brush with ink or cinnabar, as may be required, on it. He holds the wood containing the needles in his right hand, and, having put the colour on them, he rests the hand on the thumb of his left hand, and then proceed; with extraordinary rapidity to puncture the skin, stopping every now and again to put on the fluid anew. Dr. Baelz counted on one occasion ten punctures per second, and as there were ten needles the person being tattooed received one hundred punctures per second. The wonder is that with such speed excellent pictures, with various degrees of shading, can be produced, but such is the fact. A skillful operator can in this way puncture the back or breast and stomach of a grown man in a day. A few hundred thousand punctures are necessary for this purpose. The patient, if he may be so styled, does not suffer so much pain as might be expected. The punctures are not very painful, they tickle rather than hurt. No blood is drawn; a circumstance which shows that the needles do not reach the cuticle, and which also explain the slight pain of the operation, and the possibility of enduring it. This, however, is not the case always, for in many parts of the body where the skin is tender, or where a deeper shade is required, some clammy blood comes slowly to the surface, and the operation becomes painful. This occurs most frequently at the knees and elbows. To be well tattooed, therefore, is taken as a sign of manly vigour and endurance. As soon as the sitting is over the punctured parts are bathed with warm water, which produce; a slight pain. The colour then comes out more clearly than before, and the patient can do as he likes. No special diet is ordered. A few hours after the operation he often has a slight feverish feeling, but this soon leaves him. After about three days the skin scales off like bran, but the tattooed parts are never irritable or sensitive, and the man goes about his work as usual. There are cases in which women have been tattooed, but these are very rare. The women are mostly dissolute who allow this to be done; but it is said that the colours come out with great clearness and beauty on the comparatively fair skins of women. Recently tattooing has been prohibited by law under the impression 